\title{
Re-Investigation of Institutional Quality and Ecological Footprint: A Case Study of Pakistan
}

\section{Muzzammil Hussain ( $\square$ MUZZAMMIL.HUSSAIN@UOG.EDU.PK)}

University of International Business and Economics https://orcid.org/0000-0002-8001-4079

\section{Hira Yousaf}

COMSATS University Islamabad

\section{Research}

Keywords: Institutional Quality, Economic growth, Ecological footprint, Energy consumption, NARDL, Pakistan.

Posted Date: November 20th, 2020

DOI: https://doi.org/10.21203/rs.3.rs-108808/v1

License: (1) This work is licensed under a Creative Commons Attribution 4.0 International License. Read Full License 
11 Abstract

\section{Re-investigation of institutional quality and ecological footprint: A case study of Pakistan}

Hira Yousaf

hiravirk11@yahoo.com

Comsats University, Islamabad, Pakistan

Muzzammil Hussain*(Corresponding author)

Muzzammil.hussain@uog.edu.pk

University of International Business and Economics, Beijing, 100029, China

University of Gujrat, Pakistan

The discourse on the environment and growth nexus has been an important research agenda. However, the debate on the role of institutional quality (IQ) in environmental degradation is not adequate. Unlike others, this study examines the asymmetric effect of IQ towards ecological footprint (EF) from 1984 to 2014 in Pakistan. The non-linear autoregressive distributive lag model revealed that positive shocks are negatively effecting EF and negative shocks are positively effecting EF. Our findings suggest that a better IQ is substantially reducing EF, whereas energy consumption and economic growth are increasing EF. The study has robust policy implications.

Keywords: Institutional Quality; Economic growth; Ecological footprint; Energy consumption; NARDL; Pakistan.

\section{Introduction}

The institutional quality is essential for economic development around the globe. The IQ referred to the strategies that implement legitimate and cultural rules that lead to financial and socio-economic actions, which had a strong effect on the movement against environmental degradation. Higher quality institutions pave the way to 
27 eradicate corruption, hold the rule of law, the minimum intervention of the military in politics, transparency, and better management of fiscal policy and vice versa. (Sherani, 2017). Implementation of government policies is not easier for inefficient 30 institutions (Acemoglu and Johnson, 2005). Varying institutional settings lead to 31 different motives for the stakeholders of energy policies. For example, according to 32 one view, countries with autocratic establishments may implement the environmental policies in a better way than the democratic countries and vice versa (Shearman and Smith, 2007; Bernauer and Koubi, 2009).

Additionally, countries with efficient IQ promote better ways to internalize environmental externalities. For example, high taxes on pollution by policy institutions promote environmental-friendly policies in the corporate sector, which 38 helps to control environmental degradation (Galinato and Chouinard, 2018). In 39 Europe, environmental degradation is reduced during the start of this century due to a better IQ. Moreover, corruption represents weaker institutional implementation which results in poor environmental performance (Damania, Fredriksson, economics, \& 2003; Pellegrini \& Gerlach, 2006; Zugravu, Millock, \& Duchene, 2008). Strong institutional developments are necessary for developing countries especially because they require investment for economic growth with a sustainable environment (Lau, 45 Choong and Eng, 2014). Therefore, the quality of institutions is a problem in the way of sustainable development in the form of environmental degradation.

47 Environmental degradation in the form of $\mathrm{CO}_{2}$ emissions is traditionally incepted 48 since the influential work of G. M. Grossman \& Krueger (1995), in which the linkage 49 of $\mathrm{CO}_{2}$ emissions and economic growth is explained. Afterward, $\mathrm{CO}_{2}$ emissions are 50 perceived as the proxy for environmental degradation. However, environmental 51 degradation is a comprehensive phenomenon, and $\mathrm{CO}_{2}$ emissions consider only a part 
52 of it. Therefore, the ecological footprint (EF) has emerged as a comprehensive

53 measure of environmental degradation. EF refers to the environment required by

54 people. According to Wackernagel \& Kitzes, (2008), “Many human activities place

55 demands on the planet's capacity, including the provision and processing of food, the

56 construction, and maintenance of housing, transportation, and the consumption of

57 goods and services". Moreover, the EF has certain advantages over $\mathrm{CO}_{2}$ emissions.

58 For example, EF highlights the direct and indirect effect of human activities on the

59 environment. The production of crops on earth is direct to the effect of EF on the

60 environment, whereas the use of energy in the production and cultivation of crops is

61 an indirect effect (Ulucak and Bilgili, 2018). Moreover, EF affects production as well

62 as consumption activities, which directly and indirectly worsen environmental quality.

63 Due to the higher pressure of these activities, the ecological footprint is getting scarce.

64 The scarcity of ecological resources as compared to demand is resulting in

65 environmental degradation (Khan \& Hussain, 2019). So, EF is assumed to be a better

66 measure of environmental degradation, also used by Baloch, Zhang, Iqbal, \& Iqbal

67 (2019), Danish, Hassan, Baloch, Mehmood, \& Zhang (2019), and Dogan, Ulucak,

68 Kocak, \& Isik (2020).

69 Additionally, substantial literature is evidence of environmental degradation and

70 its determinants. For example, biomass energy (Mahmood et al., 2019), renewable

71 energy (Dogan and Ozturk, 2017), financial development (Xu et al., 2018), imported

72 technologies (Danish, Wang and Wang, 2017), deforestation (Arshad et al., 2020),

73 public-private investment in energy (Shahbaz et al., 2020), natural resources (Anees

74 et al., 2019), and urbanization and renewable energy consumption (Danish and wang,

75 2019). However, the attention on the linkage of institutional quality and 
environmental degradation is limited. Moreover, the IQ and EF of a developing

country such as Pakistan could be interesting due to the following reasons.

The IQ in Pakistan is worse. According to the 2018 report on corruption by transparency international, Pakistan has owned only 33 points on the scale of 0-100. Pakistan ranked 117/180, which is seriously alarming ("Corruption Perceptions Index 81 2018-Transparency International"). The rule of law is also weak in Pakistan. According to the "World Justice Project (WJP)", Pakistan is having a value of 0.39/1 in rule of law index and falls in the lower middle category ("WJP Rule of Law Index 2019 | World Justice Project"). In the presence of weak rule of law, high corruption, and lower justice; the environmental policies may not be fairly executed, which could lead to higher high EF. Being, the fifth most populous country in the world, Pakistan has utilized more ecological resources than it owns (Danish, Hassan, Baloch, Mehmood, et al., 2019). The environmental quality of Pakistan is also alarming and needs immediate attention (Danish et al., 2017; Hassan et al., 2018; Danish, Hassan, Baloch, Mahmood, et al., 2019; Mahmood et al., 2019). In Pakistan, the ecological deficit is $114 \%$ (GFN, 2018). Nonetheless, better IQ could help to minimize environmental degradation (Hassan et al., 2019). But it is not yet a priority in the eyes of environmental and institutional policymakers.

By extending the argument, this study has twofold potential contributions; firstly, it is first of its kind to investigate the asymmetric role of IQ in determining EF in Pakistan for the period 1984 to 2014. Unlike others, we use a comprehensive index of IQ developed by international country risk guide (ICRG). Secondly, we use an asymmetric autoregressive distributive lag econometric model (NARDL) to investigate the long- and short-run asymmetric relationship between the IQ and EF. Moreover, NARDL is the latest econometric approach that can handle positive and 
negative shocks of IQ. Nonetheless, IQ's positive and negative shock's effect on EF

102 in Pakistan is silent in literature. The rest of the paper consists of a literature review,

103 material and methods, a series of econometric techniques with the results and

104 discussions, and at the end conclusion with policy implications.

\section{Literature Review}

106 The literature on the linkage of IQ and EF is scarce. However, the existing papers

107 on institutional quality and $\mathrm{CO}_{2}$ emissions is summarized in table 1.

Table 1: Summary of studies on institutional quality and environmental degradation

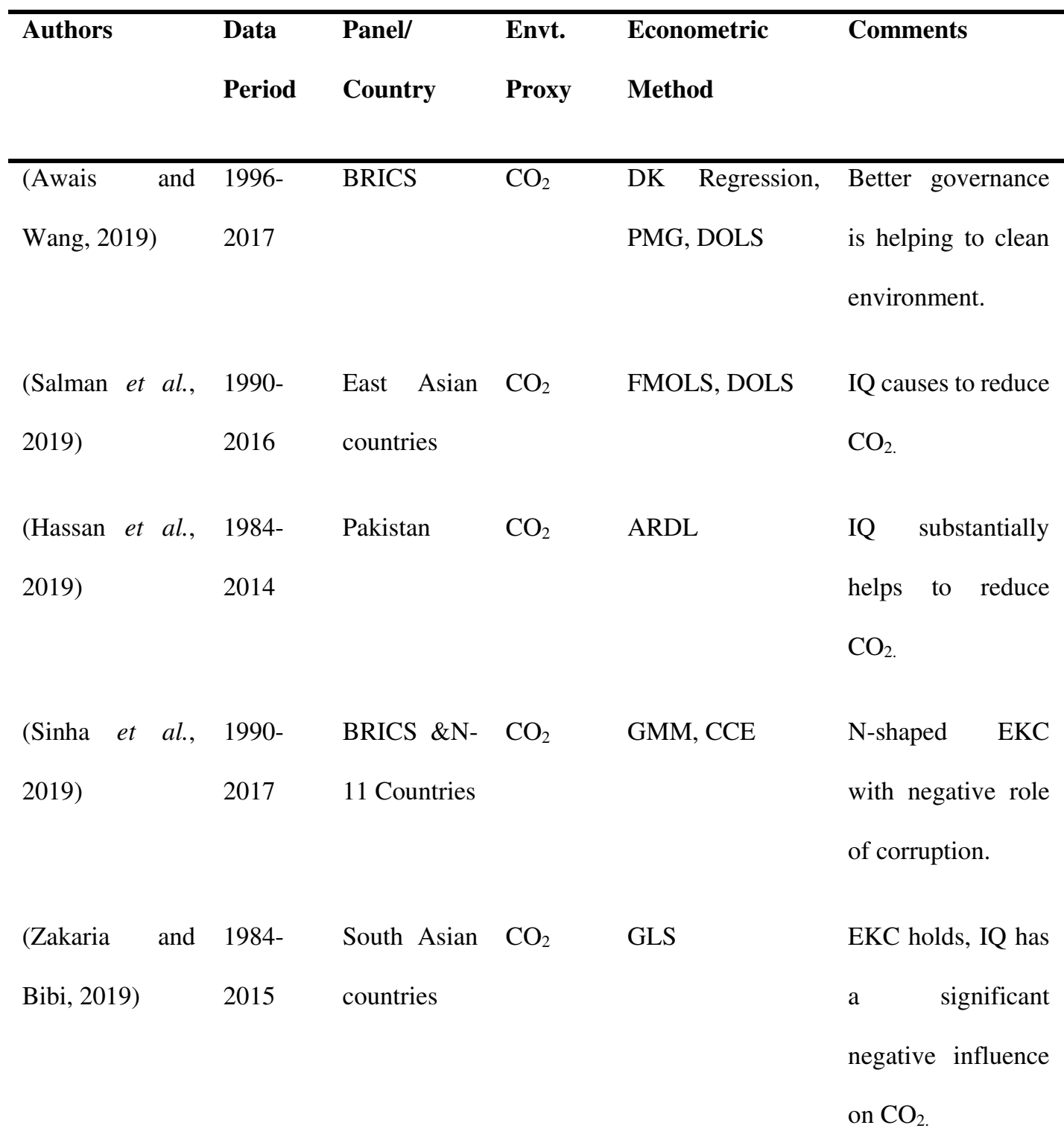




\begin{tabular}{|c|c|c|c|c|c|}
\hline (Galinato and & 1984- & European & ER & SDM, FE, RE & Better IQ directly \\
\hline Chouinard, & 1996 & countries & & & affects ER. \\
\hline 2018) & & & & & \\
\hline (Goel, Herrala & 2004- & 100 & $\mathrm{CO}_{2}$ & 2SLS & More \\
\hline and Mazhar, & 2007 & countries & & & nations with \\
\hline 2013) & & & & & shadow economies \\
\hline & & & & & have low $\mathrm{CO}_{2}$. \\
\hline (Abid, 2017) & 1990- & MEA & $\mathrm{CO}_{2}$ & GMM & IQ can help to \\
\hline & 2011 & EU(99 & & & foster \\
\hline & & countries & & & environmental \\
\hline & & & & & quality \\
\hline (Amuakwa- & 1990- & Sub- & $\mathrm{CO}_{2}$ & GMM & Quality \\
\hline Mensah and & 2011 & Saharan & & & institutions \\
\hline Adom, 2017) & & African & & & promotes quality of \\
\hline & & countries & & & environment \\
\hline & & & & & without EKC \\
\hline (Lau, Choong & $2002-$ & 100 & $\mathrm{CO}_{2}$ & GMM & Inverted U-shaped \\
\hline and $\mathrm{Ng}, 2018$ ) & 2014 & developed & & & EKC holds with a \\
\hline & & and & & & significant \\
\hline & & developing & & & negative \\
\hline & & countries & & & relationship \\
\hline & & & & & between IQ and \\
\hline & & & & & $\mathrm{CO}_{2}$ emissions. \\
\hline (Bhattacharya, & 1991- & 85 countries & $\mathrm{CO}_{2}$ & GMM, FMOLS & IQ has a positive \\
\hline Awaworyi & 2012 & & & & effect on GDP and \\
\hline Churchill and & & & & & a negative effect on \\
\hline Paramati, 2017) & & & & & $\mathrm{CO}_{2}$. \\
\hline
\end{tabular}




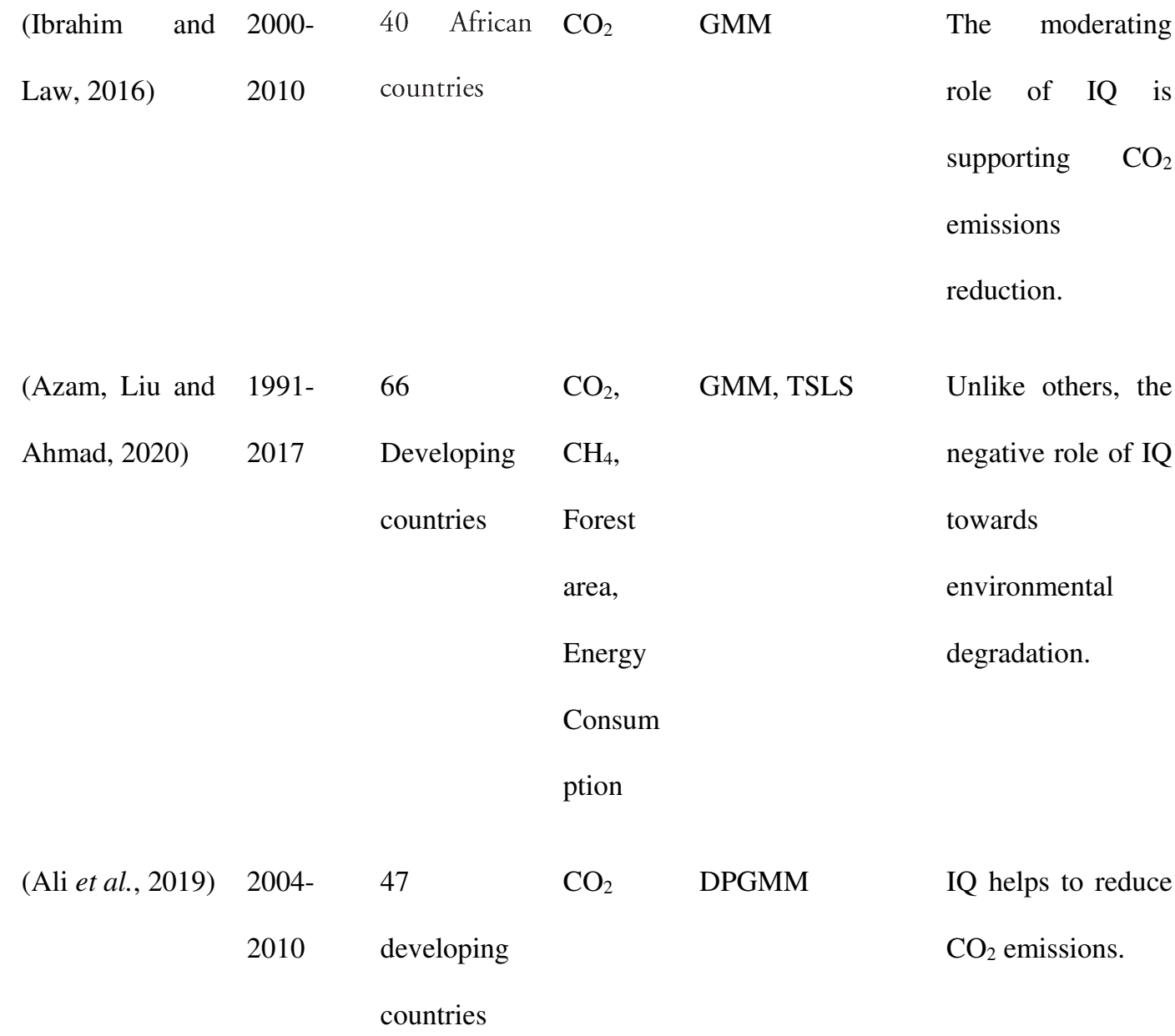

Note: ER=Environmental regulation, $\mathrm{SDM}=$ Spatial Durbin Model

109 All the above-mentioned studies considered the role of institutions in different 110 panels of developed and countries by using $\mathrm{CO}_{2}$ emissions as a measure of 111 environmental degradation. Against this background, it can be concluded that the 112 literature is scarce in explaining the role of IQ towards EF. Moreover, in the best 113 knowledge of the authors, no previous study has investigated the role of IQ, energy 114 consumption and economic growth in determining EF in Pakistan. So, this study is an 115 effort to contribute to the existing body of knowledge by using the latest data 116 available. 
Theoretically, we followed the seminal work of G. Grossman \& Krueger (1991), in which the environmental effects of trade are introduced. Moreover, the relationship between economic growth and environmental degradation is intrigued (Grossman and

122 Krueger, 1995). Afterward, environment and growth nexus in explored by a large 123 number of studies around the globe by considering different inputs of environmental degradation (Shahbaz et al., no date; Baek, 2015; Destek, Ulucak and Dogan, 2018; Ozcan, Ulucak and Dogan, 2019; Arshad et al., 2020; Khan et al., 2020). environmental degradation. Although some studies used EF as environmental degradation (Apergis and Ozturk, 2015; Danish, Hassan, Baloch, Mehmood, et al., 2019; Dogan et al., 2020), the literature on institutional quality and ecological footprint's nexus is silent. Therefore, to contribute to the energy, growth, and environment nexus by adding the role of IQ is a target to be investigated. Following equation reflect the hypothesized model;

$$
E F=f(G D P, E C, I Q)
$$

134 In the following econometric form; the natural $\log$ of all the variables is also 135 calculated:

$$
\log E F=\alpha_{0}+\alpha_{1} \log E C_{t}+\alpha_{2} \log G D P_{t}+\alpha_{3} \log I Q_{t}+\mu
$$

where EF is representing ecological footprint, IQ is institutional quality, EC is energy consumption and GDP is economic growth per capita. $t$ is the period for which data is used and $\mu$ is the error term. As, energy is one of the major production inputs and it has a direct relationship with the level of production of goods, so it leads to

141 increase EF. Therefore, the sign of $\alpha_{1}$ is expected to be positive. Similarly, the GDP is also assumed to increase EF and the sign of $\alpha_{2}$ is expected to be positive. IQ's role 
143 is crucial in abating environmental degradation. Therefore, the better quality of 144 institutions may help to reduce EF, which leads to the idea that quality institutions can 145 help to reduce the ecological deficit and $\alpha_{3}$ 's sign is anticipated to be negative.

\subsection{Data and Econometric Techniques}

Annual data is used for the period starting from 1984 to 2014. The sample period is selected on the availability of the data. For Institutional quality, 12 point ICRG's index is used for the calculation of a single index. ICRG's index for IQ is a comprehensive index also used by (Calderón, Duncan and Schmidt-Hebbel, 2016; Asif and Majid, 2018; Nawaz et al., 2018). The data of ecological footprint in collected " Global Footprint Network (GFN)". The ecological footprint is measured as ecological consumption per capita. Economic growth is assumed as GDP per capita (constant 2005 US\$), energy consumption is "the fossil fuel energy uses as a percentage of the total" and data is extracted from world development indicators (WDI).

As time-series data is used in this study and non-stationarity of the time series data is a serious issue, which may lead to spurious results. To check the stationarity of the data; the unit root test is applied. "Augmented Dickey-Fuller (ADF), Dickey-Fuller GLS (ERS), and Phillips Pearson (PP)" techniques are traditionally used firstgeneration unit root tests, but to identify structural breaks in the time series data, we apply Zivot \& Andrews, (1992) unit root test". Additionally, we applied the "Nonlinear autoregressive distributive lag (NARDL)" model, which is developed by (Shin, Yu and Greenwood-Nimmo, 2014). NARDL is an extended version of ARDL, which was initially introduced by (Pesaran, Shin and Smith, 2001a) and also extended with the name of hidden co-integration (Granger and Yoon, 2002; Schorderet, 2003). Moreover, NARDL is used to test asymmetric or symmetric relationships and it is 
equally beneficial for the small data set and it simultaneously deals with short- and long-run integration. If the variables having asymmetric relation, then the NARDL technique is used but in the case of the symmetric or linear relationship, linear ARDL

171 is used. The advantage of opting NARDL is that it can handle the positive and negative 172 shocks of the targeted variable, which can help to understand the actual properties of 173 that variable. So, to estimate NARDL, following (Pesaran, Shin and Smith, 2001a), 174 error correction approach is adopted in the following form.

$$
{ }_{\Delta} \log E F_{t}=\lambda+\sum_{k=1}^{A} \lambda_{K} \Delta \log E F_{t-k}+\sum_{k=1}^{B} \lambda_{K} \Delta \log E C_{t-k}+\sum_{k=1}^{C} \lambda_{K} \Delta \log G D P_{t-k}+
$$

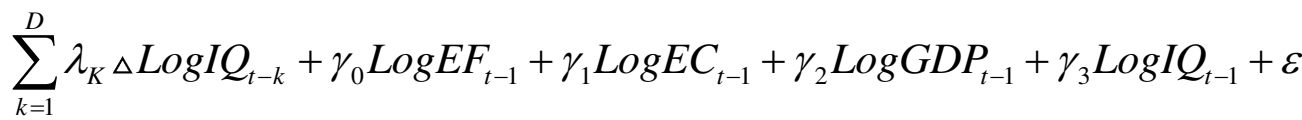
Nevertheless, there is a minor alteration, to estimate short and long term effects by replacing the lag of the error term. Long run coefficients are $\lambda \mathrm{A}, \lambda \mathrm{B}, \lambda \mathrm{C}$ and $\lambda \mathrm{D}$ whereas short-run are identified are $\lambda 0, \lambda 2, \lambda 2$, and $\lambda 3$. In the equation mentioned above, the asymmetric relationship is hypothesized, in the pursuit of this hypothesis, all the independent variables are decomposed into the negative and positive sums. This can be shown in the form of asymmetric regression; representative of independent variables and decomposed as under;

$$
x_{t}=x_{0}+x_{t}^{+}+x^{+}
$$

Where $x^{+}$and $x^{-}$are the assumed independent variables with a partial sum of positive and negative changes. Following equations are the partial sums of the negative and positive changes in institutional quality; 


$$
\log I Q^{-}=\sum_{i=1}^{t}{ } \log I Q_{i}^{-}=\sum_{i=1}^{t} \max \left(\Delta \log I Q_{i}, 0\right)
$$

193 in equations 3, 4 are combined in the following way in equation 2 . This equation is 194 developed by (Shin, Yu and Greenwood-Nimmo, 2014).

$$
{ }_{\Delta} \log E F_{t}=\lambda+\sum_{k=1}^{A} \lambda_{K} \Delta \log E F_{t-k}+\sum_{k=1}^{B} \lambda_{K} \Delta \log E C+\sum_{k=1}^{C} \lambda_{K} \Delta \log G D P_{t-k}+\sum_{k=1}^{D} \lambda_{K} \Delta \log I Q_{t-k}^{+}+\sum_{k=1}^{E} \lambda_{K} \Delta \log I Q_{t-k}^{-}+\gamma_{0} \log E F_{t-1}
$$

$+\gamma_{1}{\log E C_{t-1}}_{1} \gamma_{2} \log G D P_{t-1}+\gamma_{3} \log I Q_{t-1}^{+}+\gamma_{4} \log I_{t-1}^{-}+\varepsilon$

where $\Delta$ is difference operator, $\lambda(A, B, C, D, E)$ are the long-run coefficients and $\varepsilon$ is the error term, $\lambda_{1}, \lambda_{2}, \lambda_{3}, \lambda_{4}$ are the short-run coefficients.

\subsection{Results}

To check the stationarity of the data, the ZA unit root test applied and the results of the stationarity are given in table 2 . As shown in the results, all the variables are non-stationary at the level and after taking the first difference they become stationary. Different time breaks are also visible in different variables. Ecological footprint has time break in 2007, Energy consumption got it in 2008, Institutional quality has it in 1994 and economic growth has time break in 2001. Possible reasons for these time breaks might be due to the following reasons faced by the economy, during these years.

The ecological footprint's time break in 2007 , might be due to the major economic changes i.e 2007 economic crises around the globe might affect all the economic activities in Pakistan as well. Energy consumption time break is also linked to the fact stated above and due to energy crises during the first decade of this century. Economic growth shows a time break in 2001, the possible reason is the change in government 
212 in 1999 from democratic to military and all the policies are also changed. Pakistan has

213 also adopted practical initiatives to mitigate environmental issues during this period

214 i.e. (Pakistan Environmental Protection Act, 1997), which was mainly targeted to

215 protect the environment and to smoothening sustainable development. It was

216 rejuvenated in 2003 and implemented thereafter with focused attention on

217 environmental protection issues.

Table:2 Zivot Andrew's Unit Root Test

\begin{tabular}{llllll}
\hline Variables & $\underline{\text { At Level }}$ & & \multicolumn{2}{l}{ First Difference } & \\
& T-Statistic & Time Break & T-Statistic & Time Break & $\begin{array}{l}\text { Order of } \\
\text { Integration }\end{array}$ \\
\hline LogEF & $-4.032[1]$ & 2009 & $-3.563 *[1]$ & 2007 & I(1) \\
LogEC & $-1.901[3]$ & 2008 & $-2.552 *[1]$ & 2008 & I(1) \\
LogIQ & $-2.574[6]$ & 2004 & $-4.298^{*}[1]$ & 1994 & I(1) \\
LogGDP & $-4.314[4]$ & 1996 & $-3.892 *[4]$ & 2001 & I(1) \\
\hline
\end{tabular}

218 Note: $*$ is the significance at $1 \%$.

Table 3: Non-Linear ARDL Bound Test

\begin{tabular}{cll}
\hline Test Statistics & Value & Result \\
& & \\
\hline F-Statisitc & $11.30504 * * *$ & Integration \\
\hline Note: $* * *$ shows the significance of at $1 \%$.
\end{tabular}

Note: $* * *$ shows the significance of at $1 \%$.

Table 4: Non-Linear ARDL Short-run Results

\begin{tabular}{llll}
\hline Variables & Coefficient & T-Statistics & P-Value \\
\hline & 2.525912 & 7.888682 & $0.0000^{* * *}$ \\
$\Delta \operatorname{LogEC}$ & 2.18737 & 3.198823 & $0.02481^{* *}$
\end{tabular}



$\Delta \operatorname{LogIQ}-\mathrm{P}$
$-.200098$
$-4.205370$
$0.0007 * * *$
$\Delta \operatorname{LogIQ-N}$
0.189812
2.676724
$0.0165 * *$
Constant
$-.3848564 *$
$-1.99$
0.082

Note: *,**,*** indicates significance@ $10 \%, 5 \%, 1 \%$.

Table 5: Non-Linear ARDL Long run Results

\begin{tabular}{llcl}
\hline Variables & Coefficient & T-Statistics & P-Value \\
\hline & & & \\
$\Delta \operatorname{LogEC}$ & 2.265487 & 6.685947 & $0.0000^{* * *}$ \\
$\Delta \operatorname{LogGDP}$ & 4.16805 & 5.287846 & $0.00161^{* * *}$ \\
$\Delta \operatorname{LogIQ-P}$ & -0.179468 & -4.141841 & $0.0008^{* * *}$ \\
$\Delta \operatorname{LogIQ-N}$ & 0.170242 & 2.775125 & $0.0135^{* *}$ \\
\hline
\end{tabular}

220 Note: $\mathrm{P}$ and $\mathrm{N}$ are a positive and negative component of regressors. $* * *, * * *$ shows significance at $22110,5 \& 1 \%$

Table 6: Short and Long-run Asymmetry Results

\begin{tabular}{lllll}
\hline & \multicolumn{2}{c}{ Short-run asymmetry } & \multicolumn{2}{c}{ Long run asymmetry } \\
\cline { 2 - 2 } Regressor & F- Statistics & P-Value & F- Statistics & P-Value \\
\hline LogIQ & 1.452 & 0.27 & 1.760 & 0.18 \\
\hline
\end{tabular}

222 Note: Wald test is used to check the asymmetric results.

Table 7: ARDL Bounds Test

F-statistic Decision $\operatorname{LogEF}=f(\operatorname{LogIQ}, \log G D P, \operatorname{LogEC})$

223 Note: ***Represent a significance level of @ 1\%.

224 Non-linear ARDL bound test is applied and the results are reported in table 3. The

225 bound test is used to verify the co-integration between the variables. The value of F-

226 statistics is greater than the upper bound value at any level of significance, so it is

227 verified that co-integration exists between the variables. In table 4, short-run NARDL

228 results are reported. To find the asymmetric or non-linear relationship between IQ and 

asymmetric approach, IQ is composed of two components; positive shocks and negative shocks. Interestingly, positive and negative shocks of IQ are significantly 232 effecting the ecological footprint in the short-run in Pakistan. Positive shocks are 233 negatively and significantly effecting ecological footprint and negative shocks are positively and significantly affecting ecological footprint.

Table 5 reports the long-run NARDL results obtained through asymmetric ARDL. According to the reported results of long-run asymmetric results, IQ's negative shocks

237 are positively effecting the ecological footprint and positive shocks are negatively 238 effecting the ecological footprint and the intensity of both the components is 239 statistically significant. Energy consumption and economic growth are reported to be 240 significantly effecting ecological footprint in the short- and long-run. These results 241 are aligned with (Abid, 2016; Lau, Choong, Ng, Liew, \& Ching, 2018; Mavragani, 242 Nikolaou, Tsagarakis, \& Rosen, Marc A, 2016). In table 6, the asymmetry diagnostic 243 Wald test is reported, according to the short and long run asymmetry test results, the 244 null hypothesis of no asymmetry is accepted and the alternative hypothesis of 245 asymmetry is rejected. So, it is found that there is no asymmetric relationship between 246 institutional quality and ecological footprints. Therefore, these results are suggesting 247 the linear ARDL model for further analysis.

248 The next step is to check the linear co-integration, for that linear ARDL bound 249 testing is adopted, which is proposed by (Pesaran, Shin, and Smith, 2001b). It provides 250 dynamic results and has exceptional properties. The results of bound testing are shown 251 in table 7. The value of F-statistic is greater than the upper bound value at $1 \%$. It 252 means the existence of co-integration between the underlying variables; ecological 253 footprint, economic growth, energy consumption, and institutional quality. These 
results are consistent with (Shahbaz, Zeshan, and Afza, 2012; Danish et al., 2017;

255 Mahmood, Wang, and Hassan, 2019).

Dynamic Multipliers Graph in figure 1 reflects the asymmetry in the long run due 257 to positive and negative shocks. The symmetric or difference curve indicates the 258 combinations of dynamic multipliers due to both positive and negative shocks to IQ 259 (institutional quality). The IQ-positive and negative shocks reported information of asymmetric adjustment of ecological footprint to negative and positive shocks of IQ.

261 The results show that ecological footprints respond to negative and positive equally 262 in the short run as well as in the long run.

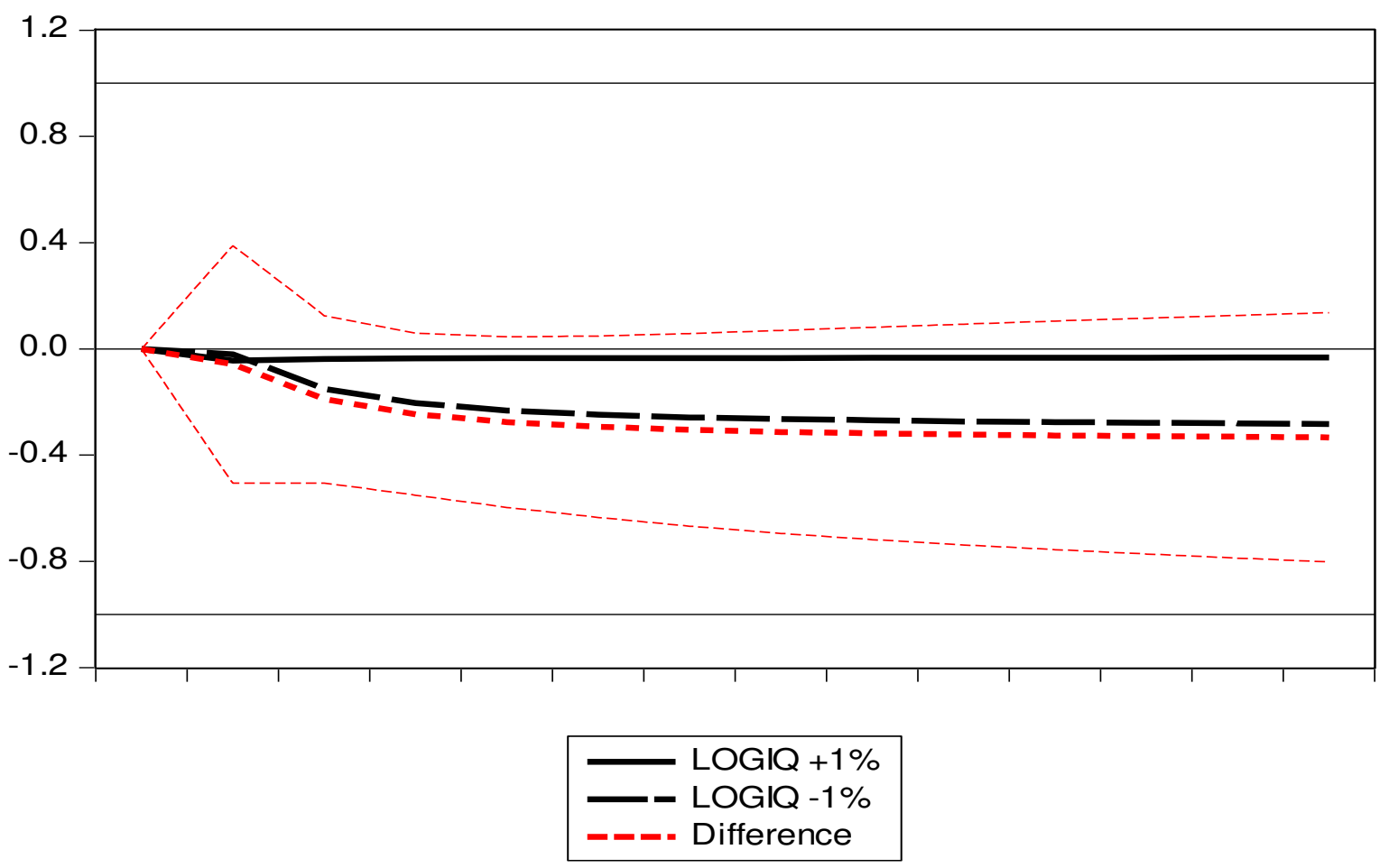

Figure: 1 Dynamic Multipliers Graph

For the robustness of the results stability statistics helped to satisfy the confirmation. "cumulative sum of residuals (CUSUM)" and "cumulative sum of the square of residuals (CUSUM) ${ }^{2}$ " diagnostic tests are selected to serve the purpose. Figure 1 is evident of the fact in which the CUSUM test shows the blue line in between the red lines, which is the confirmation of the stability of the model applied. Similarly, 
271 the robustness in the form of the blue line lies within the critical region.

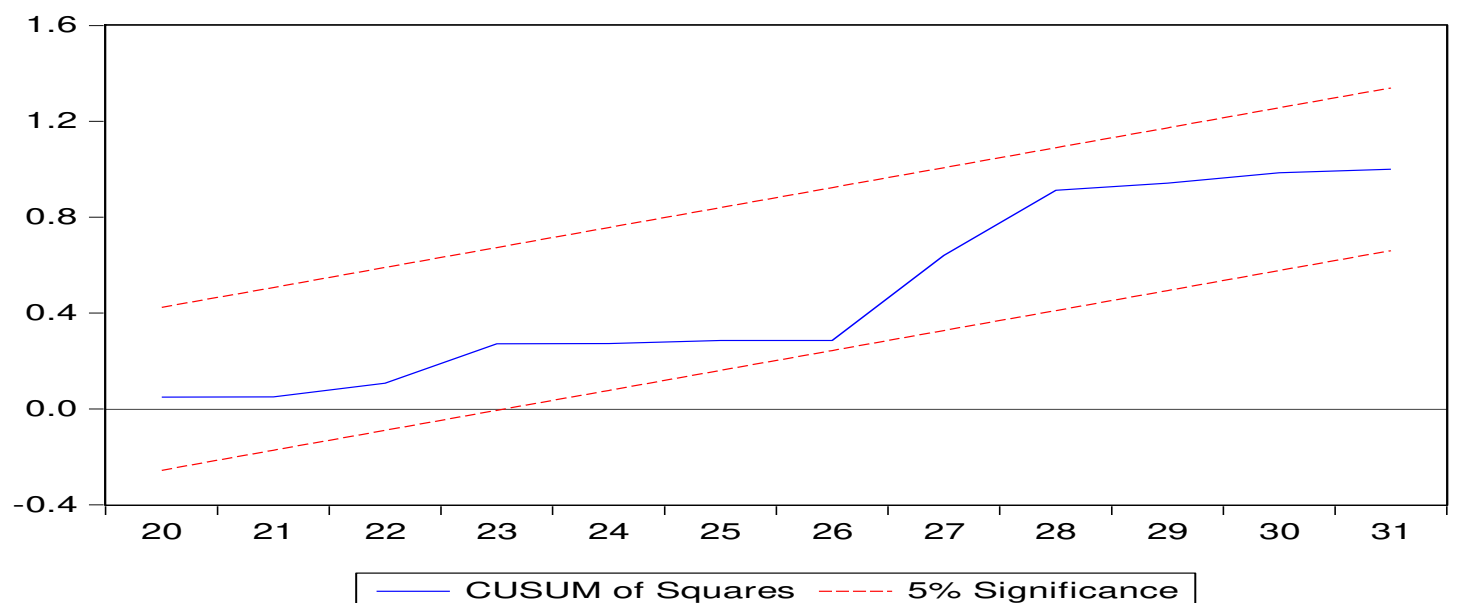

Figure 2: Robustness by CUSUM Test

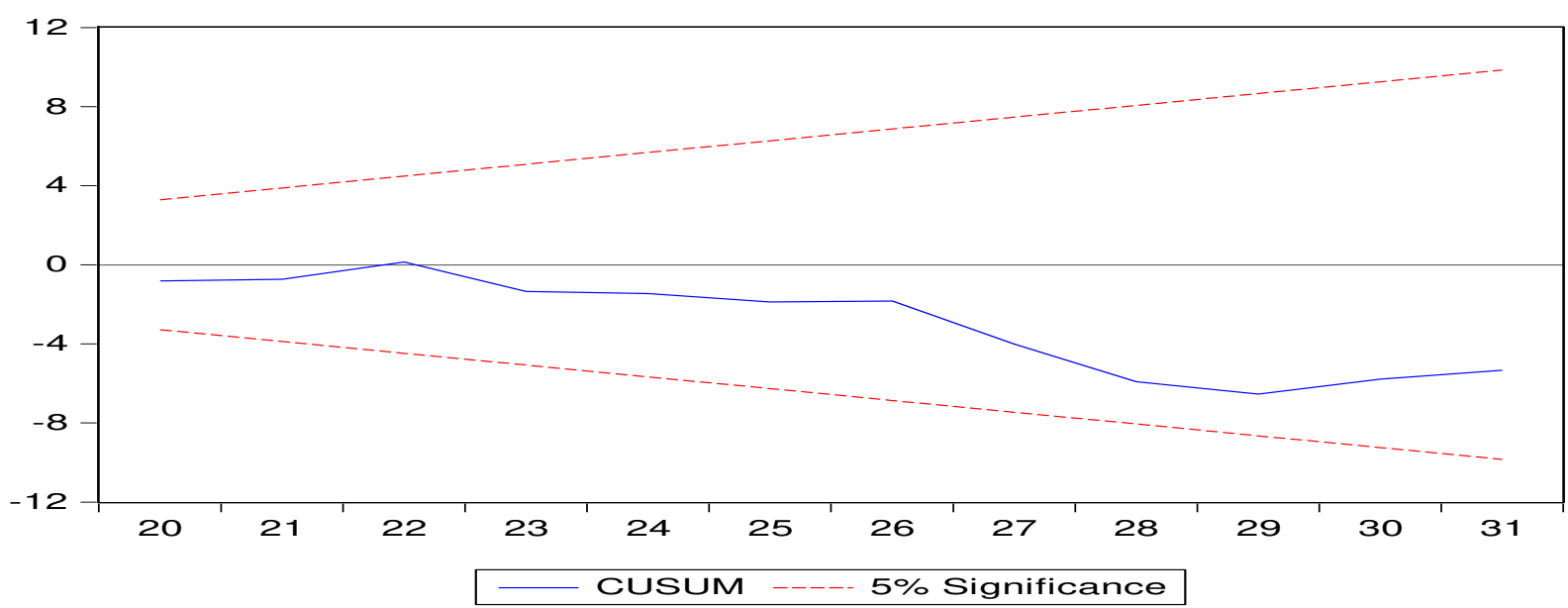

\subsection{Discussion}

Based on the findings stated-above in the result section, further discussion can be extended in the following ways. Firstly, the asymmetric effect of IQ is categorically tested against EF. Interestingly, findings of NARDL showed that IQ's positive shocks are negatively effecting the EF, which means that good quality of institutions can help

281 to reduce EF in Pakistan. Moreover, strong IQ (positive shocks) helps to promote a 

(negative shocks) is worsening the environment. Therefore, IQ can be used as a tool to control EF. By doing so, environmental degradation can be minimized in the shortand long-run (Hassan et al., 2019).

Secondly, energy consumption's role is found to be negative in determining EF. It means the EC is responsible for the weak quality of the environment. Fossil fuel energy consumption with a share of $80 \%$ in the total energy consumption is dominating (Baloch, Kaloi, and Memon, 2016). Therefore, the share of EC is needed to be minimized to achieve a better quality of the environment. Thirdly, the GDP is also significantly increasing the EF, which means that economic growth is one of the major reasons for high EF. Being a developing country, Pakistan is at the early development stage, which is deteriorating the environment (Arshad et al., 2020). After, a certain growth-level, environmental degradation may decrease. ecological footprint by controlling the role of EC and GDP for Pakistan from 1984 to 2014. The latest econometric techniques are applied to support the hypothetical linkage between the variables. Positive and negative shocks of IQ are significantly effecting the EF. The symmetric relationship is evident. Energy consumption and economic growth are increasing environmental degradation, institutional quality is helping to reduce the ecological footprint in the short-and long-run in Pakistan.

For the policymakers, the following suggestions could be helpful. Firstly, IQ is found to help in decreasing EF in Pakistan. The institutions have a substantial role to play in abating environmental degradation. Strong institutional quality could lead to 
307 consumption is found to be harmful to the environment. Policymakers should reconsider the energy sources for better environmental quality.,

Thirdly, GDP is also increasing the EF. As a developing country, Pakistan's economic growth's goal is inevitable but the environmental aspect should not be ignored. Sustainable growth policies are needed to achieve better environmental quality. Lastly, educational institutions and media houses can play their role in the awareness about environmental degradation and its seriousness. Local governments could take immediate steps at sub-division as well as the union council level to promote awareness in local institutions to motivate every stakeholder. Further investigation of the phenomenon can elaborate on more detailed results. Future studies can use other measures of institutional quality and environmental quality to observe this phenomenon in other parts of the world.

\section{Ethics approval and consent to participate}

All the authors hereby agree to give consent on ethical approval as per the terms and conditions given in the guidelines.

\section{Consent for publication}

The authors hereby agree to give consent for publication of the manuscript.

\section{Availability of data and material}

$$
\text { Data will be made available on demand. }
$$

\section{Competing interests}

All the authors hereby agree to give consent that they have no competing interests related to the paper.

\section{Funding}

For this paper no funding in received.

\section{Authors' contributions}


All the authors contributed equally in conceptualization, methodology, writing,

and editing of the paper.

\section{Acknowledgement}

Authors acknowledge that the paper is based on original work and never

published or under review anywhere else.

\section{References}

Abid, M. (2016) 'Impact of economic, fi nancial , and institutional factors on CO 2 emissions : Evidence from Sub-Saharan Africa economies', Utilities Policy. Elsevier Ltd, 41, pp. 85-94. doi: 10.1016/j.jup.2016.06.009.

Abid, M. (2017) 'Does economic, financial and institutional developments matter for environmental quality? A comparative analysis of EU and MEA countries', Journal of Environmental Management. Academic Press, 188, pp. 183-194. doi: 10.1016/J.JENVMAN.2016.12.007.

Acemoglu, D. and Johnson, S. (2005) 'Unbundling Institutions', Journal of Political Economy. The University of Chicago Press , 113(5), pp. 949-995. doi: 10.1086/432166.

Ali, H. S. et al. (2019) 'Does quality institutions promote environmental quality?', Environmental Science and Pollution Research. Springer Berlin Heidelberg, 26(11), pp. 10446-10456. doi: 10.1007/s11356-019-04670-9.

Amuakwa-Mensah, F. and Adom, P. K. (2017) 'Quality of institution and the FEG (forest, energy intensity, and globalization) -environment relationships in subSaharan Africa', Environmental Science and Pollution Research. Springer Berlin Heidelberg, 24(21), pp. 17455-17473. doi: 10.1007/s11356-017-9300-2.

Anees, S. et al. (2019) 'The impact of globalization, natural resources abundance, and human capital on financial development: Evidence from thirty-one OECD countries', Resources Policy. Elsevier Ltd, 64(August), p. 101476. doi: 10.1016/j.resourpol.2019.101476.

Apergis, N. and Ozturk, I. (2015) 'Testing Environmental Kuznets Curve hypothesis in Asian countries', Ecological Indicators. Elsevier, 52, pp. 16-22. doi: 10.1016/J.ECOLIND.2014.11.026.

Arshad, Z. et al. (2020) 'The effects of deforestation and urbanization on sustainable growth in Asian countries', Environmental Science and Pollution Research.

Environmental Science and Pollution Research, (2016). doi: 10.1007/s11356-01907507-7.

Asif, M. and Majid, A. (2018) 'Institutional quality, natural resources and FDI: empirical evidence from Pakistan', Eurasian Business Review. Springer International Publishing, 8(4), pp. 391-407. doi: 10.1007/s40821-017-0095-3. Awais, M. and Wang, B. (2019) 'Analyzing the role of governance in CO 2 
emissions mitigation: The BRICS experience', Structural Change and Economic Dynamics. Elsevier B.V., 51, pp. 119-125. doi: 10.1016/j.strueco.2019.08.007.

Azam, M., Liu, L. and Ahmad, N. (2020) 'Impact of institutional quality on environment and energy consumption: evidence from developing world', Environment, Development and Sustainability. Springer Science and Business Media LLC, pp. 1-22. doi: 10.1007/s10668-020-00644-X.

Baek, J. (2015) 'Environmental Kuznets curve for CO2 emissions: The case of Arctic countries', Energy Economics. North-Holland, 50, pp. 13-17. doi: 10.1016/J.ENECO.2015.04.010.

Baloch, M. A. et al. (2019) 'The effect of financial development on ecological footprint in BRI countries: evidence from panel data estimation', Environmental Science and Pollution Research. Environmental Science and Pollution Research, 26(6), pp. 6199-6208. doi: 10.1007/s11356-018-3992-9.

Baloch, M. H., Kaloi, G. S. and Memon, Z. A. (2016) 'Current scenario of the wind energy in Pakistan challenges and future perspectives: A case study', Energy Reports. Elsevier Ltd, 2, pp. 201-210. doi: 10.1016/j.egyr.2016.08.002.

Bernauer, T. and Koubi, V. (2009) 'Effects of political institutions on air quality', Ecological Economics. Elsevier, 68(5), pp. 1355-1365. doi: 10.1016/J.ECOLECON.2008.09.003.

Bhattacharya, M., Awaworyi Churchill, S. and Paramati, S. R. (2017) 'The dynamic impact of renewable energy and institutions on economic output and CO 2 emissions across regions', Renewable Energy, 111, pp. 157-167. doi: 10.1016/j.renene.2017.03.102.

Calderón, C., Duncan, R. and Schmidt-Hebbel, K. (2016) 'Do Good Institutions Promote Countercyclical Macroeconomic Policies?', Oxford Bulletin of Economics and Statistics. John Wiley \& Sons, Ltd (10.1111), 78(5), pp. 650-670. doi: 10.1111/obes. 12132 .

Corruption Perceptions Index 2018 - Transparency International (no date). Available at: https://www.transparency.org/cpi2018 (Accessed: 12 August 2019).

Damania, R. et al. (no date) 'Trade liberalization, corruption, and environmental policy formation: theory and evidence', Elsevier. Available at: https://www.sciencedirect.com/science/article/pii/S0095069603000251 (Accessed: 13 October 2019).

Danish et al. (2017) 'Role of renewable energy and non-renewable energy consumption on EKC: Evidence from Pakistan', Journal of Cleaner Production. Elsevier B.V., 156, pp. 855-864. doi: 10.1016/j.jclepro.2017.03.203.

Danish, Hassan, S. T., Baloch, M. A., Mehmood, N., et al. (2019) 'Linking economic growth and ecological footprint through human capital and biocapacity', Sustainable Cities and Society. Elsevier, 47(March), p. 101516. doi: 10.1016/j.scs.2019.101516.

Danish, Hassan, S. T., Baloch, M. A., Mahmood, N., et al. (2019) 'Linking 
economic growth and ecological footprint through human capital and biocapacity', Sustainable Cities and Society, 47, p. 101516. doi: 10.1016/j.scs.2019.101516.

Danish, Wang, B. and Wang, Z. (2017) 'Imported technology and CO 2 emission in China : Collecting evidence through bound testing and VECM approach', Renewable and Sustainable Energy Reviews. Elsevier Ltd, (November), pp. 1-11. doi: 10.1016/j.rser.2017.11.002.

Danish and wang, Z. (2019) 'Investigation of the ecological footprint's driving factors: What we learn from the experience of emerging economies', Sustainable Cities and Society. Elsevier B.V., 49, p. 101626. doi: 10.1016/j.scs.2019.101626.

Destek, M. A., Ulucak, R. and Dogan, E. (2018) 'Analyzing the environmental Kuznets curve for the EU countries: the role of ecological footprint', Environmental Science and Pollution Research. Springer Berlin Heidelberg, 25(29), pp. 29387 29396. doi: 10.1007/s11356-018-2911-4.

Dogan, E. et al. (2020) 'The use of ecological footprint in estimating the Environmental Kuznets Curve hypothesis for BRICST by considering cross-section dependence and heterogeneity', Science of the Total Environment. Elsevier B.V., 723. doi: 10.1016/j.scitotenv.2020.138063.

Dogan, E. and Ozturk, I. (2017) 'The influence of renewable and non-renewable energy consumption and real income on CO2emissions in the USA: evidence from structural break tests', Environmental Science and Pollution Research. doi: 10.1007/s11356-017-8786-y.

Engle, R. F. and Granger, C. W. J. (1987) 'Co-Integration and Error Correction: Representation, Estimation, and Testing', Econometrica. The Econometric Society, 55(2), p. 251. doi: 10.2307/1913236.

Galinato, G. I. and Chouinard, H. H. (2018) 'Strategic interaction and institutional quality determinants of environmental regulations', Resource and Energy Economics. North-Holland, 53, pp. 114-132. doi: 10.1016/J.RESENEECO.2018.04.001.

GFN, 2018 (no date) GFN, 2018. Available at: http://data.footprintnetwork.org/\#/countryTrends?type $=$ BCtot,EFCtot $\% 26 \mathrm{cn}=165$ (Accessed: 24 June 2019).

Goel, R. K., Herrala, R. and Mazhar, U. (2013) 'Institutional quality and environmental pollution: MENA countries versus the rest of the world', Economic Systems, 37(4), pp. 508-521. doi: 10.1016/j.ecosys.2013.04.002.

Granger, C. W. J. and Yoon, G. (2002) 'Hidden Cointegration', SSRN Electronic Journal. doi: 10.2139/ssrn.313831.

Grossman, G. and Krueger, A. (1991) 'Environmental impacts of a North American free trade agreement'. Available at: https://www.nber.org/papers/w3914 (Accessed: 12 May 2019).

Grossman, G. M. and Krueger, A. B. (1995) 'Economic Growth and the Environment', The Quarterly Journal of Economics. Narnia, 110(2), pp. 353-377. 
453 Hassan, M. S. et al. (2018) 'Natural Gas Consumption and Economic Growth in

454 Pakistan: Production Function Approach', Global Business Review. SAGE

455 PublicationsSage India: New Delhi, India, 19(2), pp. 297-310. doi:

$45610.1177 / 0972150917713533$.

457 Hassan, S. T. et al. (2019) 'Role of institutions in correcting environmental pollution: An empirical investigation', Sustainable Cities and Society, p. 101901. doi: 10.1016/j.scs.2019.101901.

Ibrahim, M. H. and Law, S. H. (2016) 'Institutional Quality and $\mathrm{CO}_{2}$ EmissionTrade Relations: Evidence from Sub-Saharan Africa', South African Journal of Economics. John Wiley \& Sons, Ltd (10.1111), 84(2), pp. 323-340. doi: 10.1111/saje.12095. Analysis of Ecological Footprint of Rural-Urban Households in Islamabad. Available at: http://www.pide.org.pk (Accessed: 9 May 2019).

Khan, Z. et al. (2020) 'Consumption-based carbon emissions and international trade in G7 countries: The role of environmental innovation and renewable energy', Science of The Total Environment. Elsevier, p. 138945. doi:

471 Lau, L.-S. et al. (2018) 'Is nuclear energy clean? Revisit of Environmental Kuznets

472 Curve hypothesis in OECD countries', Economic Modelling. Elsevier Ltd,

473 (September), pp. 1-9. doi: 10.1016/j.econmod.2018.09.015.

474 Lau, L.-S., Choong, C.-K. and Eng, Y.-K. (2014) 'Investigation of the 475 environmental Kuznets curve for carbon emissions in Malaysia: Do foreign direct 476 investment and trade matter?', Energy Policy. Elsevier, 68, pp. 490-497. doi:

477 10.1016/J.ENPOL.2014.01.002.

478 Lau, L.-S., Choong, C.-K. and Ng, C.-F. (2018) 'Role of Institutional Quality on 479 Environmental Kuznets Curve: A Comparative Study in Developed and Developing 480 Countries', in, pp. 223-247. doi: 10.1108/S2514-465020180000006007.

481 Mahmood, N. et al. (2019) 'How to bend down the environmental Kuznets curve: 482 the significance of biomass energy', Environmental Science and Pollution Research. 483 Springer Berlin Heidelberg, pp. 1-11. doi: 10.1007/s11356-019-05442-1. growth, human capital, and CO 2 emission : an empirical analysis'. Environmental Science and Pollution Research.

490 Nawaz, M. et al. (2018) 'Institutional quality and cyclicality of monetary and fiscal 491 policies in SAARC countries', Transylvanian Review of Administrative Sciences, 492 55(E), pp. 32-44. doi: 10.24193/tras.55E.3. 
493 Ozcan, B., Ulucak, R. and Dogan, E. (2019) 'Analyzing long lasting effects of 494 environmental policies: Evidence from low, middle and high income economies', 495 Sustainable Cities and Society. Elsevier, 44, pp. 130-143. doi: 10.1016/J.SCS.2018.09.025.

497 Pakistan Environmental Protection Act, 1997 (no date). Available at:

498 https://www.who.int/fctc/reporting/Pakistan_annex2_environmental_protection_act1 499 997.pdf (Accessed: 27 July 2019).

500 Pellegrini, L. and Gerlagh, R. (2006) 'Corruption, Democracy, and Environmental 501 Policy', The Journal of Environment \& Development, 15(3), pp. 332-354. doi: $50210.1177 / 1070496506290960$.

503 Pesaran, M. H., Shin, Y. and Smith, R. J. (2001a) 'Bounds testing approaches to the 504 analysis of level relationships', Journal of Applied Econometrics. John Wiley \& 505 Sons, Ltd, 16(3), pp. 289-326. doi: 10.1002/jae.616.

Pesaran, M. H., Shin, Y. and Smith, R. J. (2001b) 'Bounds testing approaches to the analysis of level relationships', Journal of Applied Econometrics, 16(3), pp. 289326. doi: 10.1002/jae.616.

Salman, M. et al. (2019) 'The impact of institutional quality on economic growth and carbon emissions: Evidence from Indonesia, South Korea and Thailand', Journal of Cleaner Production. Elsevier BV, 241, p. 118331. doi: 10.1016/j.jclepro.2019.118331.

Schorderet, Y. (2003) 'Asymmetric Cointegration Université de Genève’.

Shahbaz, M. et al. (2020) 'Public-private partnerships investment in energy as new determinant of $\mathrm{CO} 2$ emissions: The role of technological innovations in China', Energy Economics. Elsevier B.V, 86, p. 104664. doi: 10.1016/j.eneco.2020.104664.

Shahbaz, M. et al. (no date) 'Foreign direct Investment-CO2 emissions nexus in Middle East and North African countries: Importance of biomass energy consumption', Elsevier. Available at: https://www.sciencedirect.com/science/article/pii/S0959652619303099 (Accessed: 15 October 2019).

Shahbaz, M., Zeshan, M. and Afza, T. (2012) 'Is energy consumption effective to spur economic growth in Pakistan? New evidence from bounds test to level relationships and Granger causality tests', Economic Modelling. North-Holland, 29(6), pp. 2310-2319. doi: 10.1016/J.ECONMOD.2012.06.027.

Shearman, D. J. C. and Smith, J. W. (2007) The climate change challenge and the failure of democracy. Praeger Publishers.

Sherani, S. (2017) Institutional reforms in Pakistan: The missing piece of the development puzzle.

Shin, Y., Yu, B. and Greenwood-Nimmo, M. (2014) 'Modelling Asymmetric Cointegration and Dynamic Multipliers in a Nonlinear ARDL Framework', in Festschrift in Honor of Peter Schmidt. New York, NY: Springer New York, pp. 281-314. doi: 10.1007/978-1-4899-8008-3_9. 
534 Sinha, A. et al. (2019) 'Impact of corruption in public sector on environmental 535 quality: Implications for sustainability in BRICS and next 11 countries', Journal of 536 Cleaner Production. Elsevier Ltd, 232, pp. 1379-1393. doi:

537 10.1016/j.jclepro.2019.06.066.

538 Ulucak, R. and Bilgili, F. (2018) 'A reinvestigation of EKC model by ecological 539 footprint measurement for high, middle and low income countries', Journal of 540 Cleaner Production. Elsevier, 188, pp. 144-157. doi:

541 10.1016/J.JCLEPRO.2018.03.191.

542 Wackernagel, M. and Kitzes, J. (2008) 'Ecological Footprint', in Encyclopedia of 543 Ecology, Five-Volume Set. Elsevier Inc., pp. 1031-1037. doi: 10.1016/B978544 008045405-4.00620-0.

545 WJP Rule of Law Index 2019| World Justice Project (no date). Available at: 546 https://worldjusticeproject.org/our-work/publications/rule-law-index-reports/wjp547 rule-law-index-2019 (Accessed: 12 August 2019).

$548 \mathrm{Xu}, \mathrm{Z}$. et al. (2018) 'Nexus between financial development and CO2 emissions in 549 Saudi Arabia: analyzing the role of globalization', Environmental Science and 550 Pollution Research. Environmental Science and Pollution Research, 25(28), pp. 551 28378-28390. doi: 10.1007/s11356-018-2876-3.

552 Zakaria, M. and Bibi, S. (2019) 'Financial development and environment in South 553 Asia: the role of institutional quality', Environmental Science and Pollution 554 Research. Springer Berlin Heidelberg, 26(8), pp. 7926-7937. doi: 10.1007/s11356555 019-04284-1.

556 Zivot, E. and Andrews, D. W. K. (1992) 'Further Evidence on the Great Crash, the 557 Oil Price Shock, and the Unit Root Hypothesis', Journal of Business \& Economic 558 Statistics, 10(3), pp. 251-270. doi: 10.1198/073500102753410372.

559 Zugravu, N., Millock, K. and Duchene, G. (2008) 'The Factors Behind CO2 560 Emission Reduction in Transition Economies', Fondazione Eni Enrico Mattei 561 Working Papers. Available at: https://services.bepress.com/feem/paper217 562 (Accessed: 13 October 2019). 
Figures

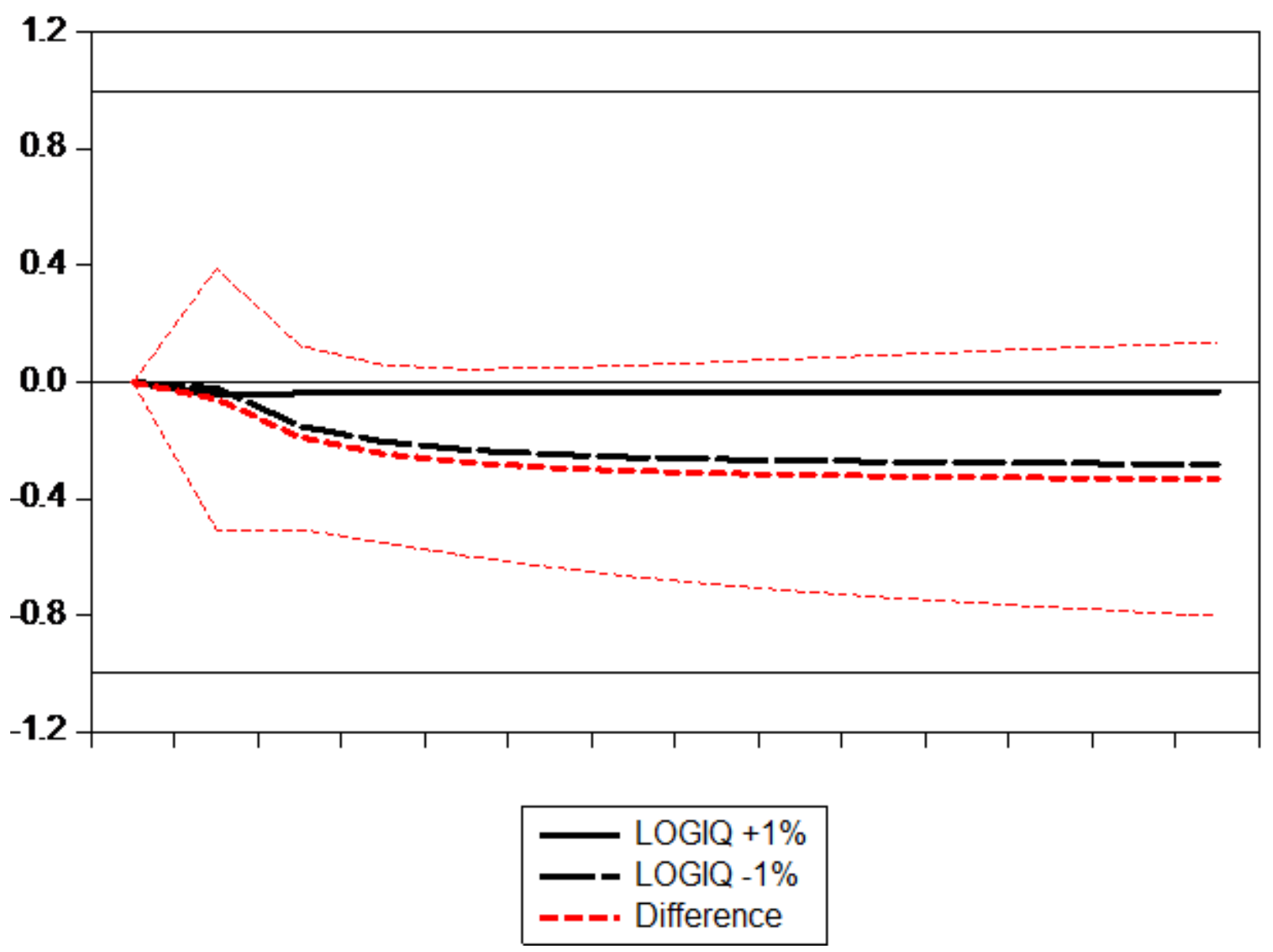

Figure 1

Dynamic Multipliers Graph 


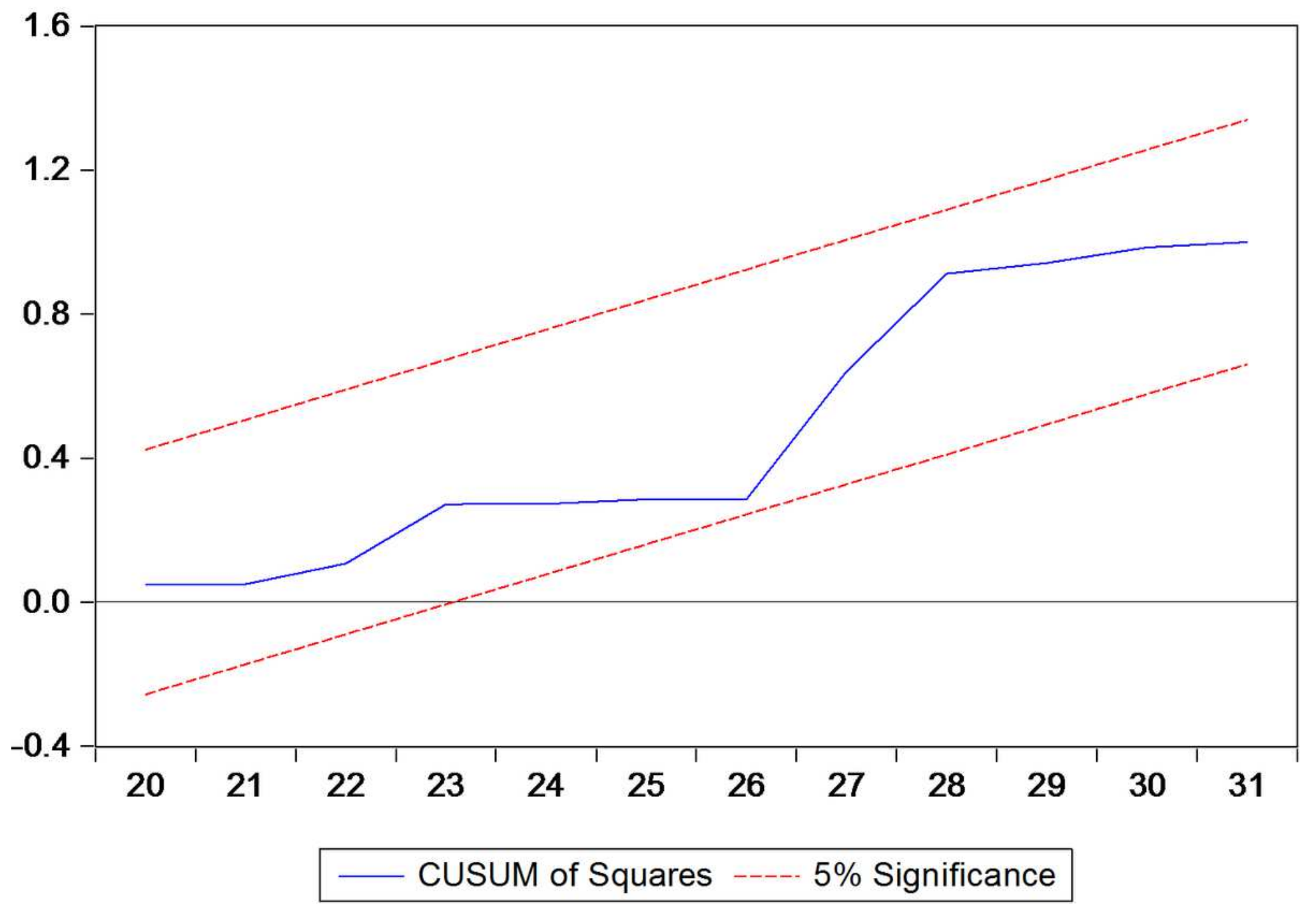

Figure 2

Robustness by CUSUM Test 


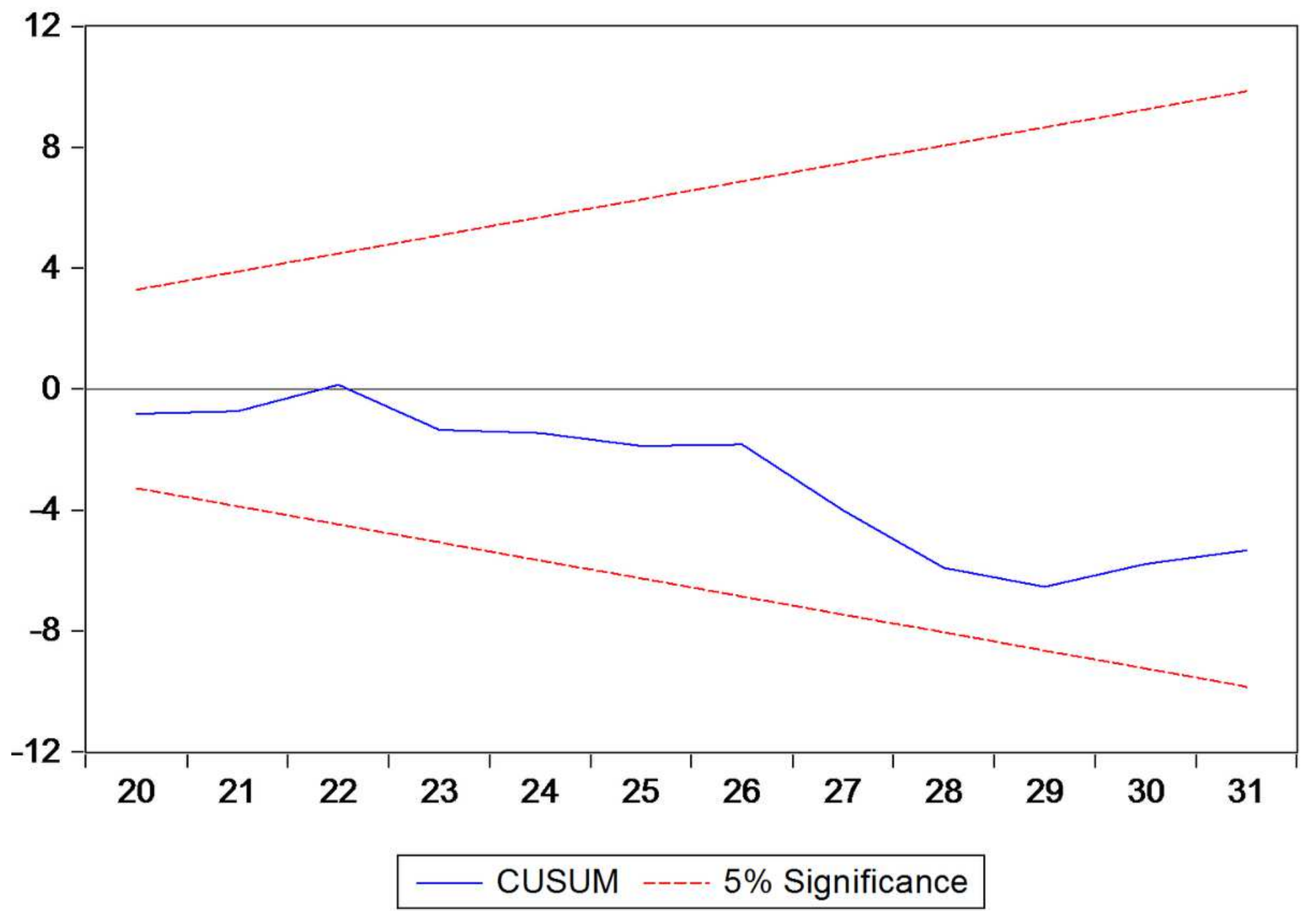

Figure 3

Robustness by CUSUM Test 